\title{
イネワラのアルカリ系蒸解における脱シリカ反応に影響する因子
}

\author{
東京大学大学院 農学生命科学研究科 朴 承榮, 松本雄二, 飯塚克介 \\ 東京大学アジア生物資源環境研究センター 飯山賢治

\section{Effect of Alkali Pulping Conditions on the Reaction of Silica Removal from Rice Straw}

\begin{abstract}
Seung-Young Park, Yuji Matsumoto and Gyosuke Meshitsuka

Graduate School of Agricultural and Life Sciences,

The University of Tokyo
\end{abstract}

\section{Kenji Iiyama}

Asian Natural Environmental Science Center,

The University of Tokyo

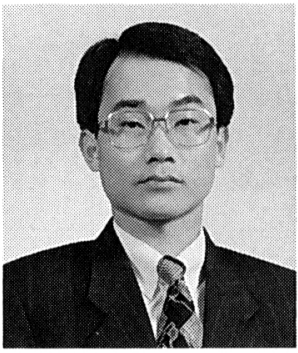

朴承榮

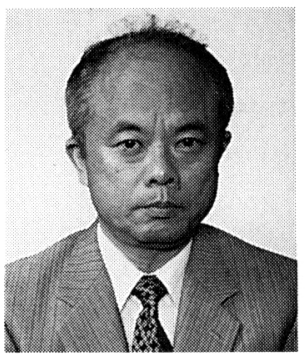

飯塚克介

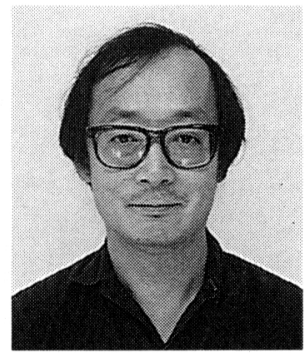

松本雄二

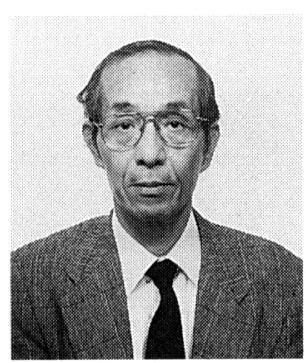

飯山賢治

Relationship between the progress of delignification and silica removal from rice straw was studied under various pulping conditions. Alkali pulping and oxygen-alkali pulping were found to remove lignin and silica significantly from pulp, while sulfite and ammonia pulping were found to retain a certain amount of silica in pulp with low lignin content. Delignification with higher carbohydrate yield can be achieved by the multi-stage process of $0.05 \mathrm{M}$ sodium alkali treatment. It was confirmed that there is a strong relationship between silica removal and the $\mathrm{pH}$ of cooking liquor. Comparison between oxygen-alkali pulping and conventional alkali pulping at the same degree of delignification shows that oxygen-alkali pulping can keep higher silica content than conventional alkali pulping probably because of lower $\mathrm{pH}$ in the former case. Oxygen-alkali pulping can, however, remove more silica under the same $\mathrm{pH}$ condition than conventional alkali pulping, which suggests the silica removal is not only dependent upon $\mathrm{pH}$ condition. Silica removal up to $30 \%$ was observed at any $\mathrm{pH}$ with various cooking liquor. However, it depends on alkali concentration and cooking temperature whether further removal of silica proceeds or not. 
Keywords: Rice straw, Silica removal, Delignification, Pulp yield, Alkaline pulping, Carbohydrate, Oxgen

\section{1. 緒言}

ワラ類は製紙産業用としてばかりでなく家畜用飼料 としても重要な非木材資源である。世界の全パルプ生 産量の中で非木材パルプの占める割合は約 $12 \%$ あ あ $\eta^{1)}$, 特にワラパルプの生産量は非木材パルプ生産量 の $50 \%$ 以上を占める ${ }^{2)}$ 。ワラのパルプ化法として実用 化されている方法，あるいは研究されている方法には， 石兏法 ${ }^{3)}$, ソーダ法 ${ }^{4)}$, クラフト法 ${ }^{5)}$, 中性サルファイ 卜法 ${ }^{6)}$, 酸素一アルカリ法 ${ }^{4), 7)-11)}$, ソーダ- $\mathrm{AQ}^{12)}$ 法 等がある。

ムギワラ，イネワラには灰分がそれぞれ 5-10\%， 15-20\%存在し，そのうちシリカが $12-18 \%$ 占める と報告されている ${ }^{13)}$ 。イネワラを原料としてパルプ生 産を行う上で最も大きな問題となるのが, イネワラ中 にこのように多量に含まれるシリカである。アルカリ 試薬によるパルプ化の際, 蒸解排液中に溶出したシリ 力が蒸解試薬を回収する上で様々な問題を引き起こす ため, 蒸解排液の回収工程は確立されていない。した がって, 排液は環境中八未処理で排出されることにな り，それによる環境污染が問題となる。そのため，非 木材繊維にパルプ原料の多くを依存している中国でも, イネワラのパルプ化が制限されつつある。このことは, パルプ原料としての木材への依存度が増大することを 意味しており, 資源問題を深刻化させる要因となりつ つある。

イネワラの蒸解過程における脱シリカ挙動に影響す る因子のうち，原料に関係するものとしては，イネ栽 培地域の土壤及び水の性質, イネの品種と組織, 細断 イネワラの大きさ等があり, 蒸解法に関するものとし ては, 蒸解薬液の種類及び濃度, 蒸解温度, 蒸解時間, $\mathrm{pH}$, 液比等が挙げられる。本研究では, 蒸解薬液の 種類と $\mathrm{pH}$ による脱シリカの挙動を詳細に検討するこ とを目的とした。

\section{2. 実験}

\section{1 供 試 試 料}

1996 年 10 月に収穫（採取地：神奈川県大井町）し たイネ（Oryza sativa L. cv. kinuhikari）を天日乾 燥したものを試料とした。イネワラのうち 40-45\%を 占める葉鞘の部分をWiley mill で粉砕した後, 篩別 機で 30 分間激しく振とうさせて 40-80 mesh 区分を 得な。これを $80 \%$ エタノール（1 時間煮沸 $\times 3$ 回）で
抽出した。

\section{2 ソーダ蒸解}

\section{2 .1 一段蒸解}

イネワラ葉鞘の粉末 $2 \mathrm{~g}$ に所定濃度の水酸化ナトリ ウム溶液 $40 \mathrm{~m} l$ を加えて $100 \mathrm{~m} l$ ステンレススチール 製高圧反応器中に密閉し，30 分間浸漬した後，シリ コンオイルバス中で振とうしながら蒸解した。水酸化 ナトリウム濃度は $0.01 \mathrm{M}, 0.05 \mathrm{M}, 0.1 \mathrm{M}, 0.2 \mathrm{M}$, $0.5 \mathrm{M}, 1.0 \mathrm{M}, 2.0 \mathrm{M}$ とし、蒸解温度 $120^{\circ} \mathrm{C}$, 蒸解 時間 2 時間，液比を $20: 1$ とした。蒸解後，1時間水 水で冷却してから $\mathrm{pH}$ を測定した。パルプの回収には $1 \mathrm{G} 3$ ガラスフィルタを用いた。パルプは十分に水洗し, 最後にアセトン $40 \mathrm{~m} l$ を用いて洗浄した後, 真空乾 燥器で $55^{\circ} \mathrm{C} 、 24$ 時間乾燥して収率を求めた。

\section{2 .2 多段蒸解}

$0.05 \mathrm{M}$ 水酸化ナトリウム溶液を用いて，2４回の 多段蒸解を行った。各段の蒸解温度, 蒸解時間, 液比 は水酸化ナトリウム一段階蒸解条件と同一とした。

\section{3 酸素アルカリ蒸解}

イネワラ葉鞘粉末 $3 \mathrm{~g}$ を用いて酸素アルカリ反応装 置中で酸素アルカリ蒸解を行った。蒸解温度 $120^{\circ} \mathrm{C}$, 蒸解温度到達時間 45 分, 保持時間 120 分, 水酸化ナ トリウム投与量を対試料 $10 \% ， 20 \% ， 40 \%$ とし，溶 液の全量を $200 \mathrm{~m} l$ とした。蒸解時の酸素圧は 0.3 $\mathrm{MPa}$ とした。蒸解前に, 酸素の導入と放出を 3 回行 い蒸解容器中の空気を酸素に置換した,

\section{4 アンモニアによる蒸解}

濃度 0.5 M, 1.0 M, 2.0 M, 4.0 M, 8.0 M, 12.0 Mのアンモニア水を用いて蒸解した。蒸解温度, 蒸 解時間, 液比は水酸化ナトリウム一段階蒸解条件と同 一とした。さらに,アンモニア濃度 $2.0 \mathrm{M}, 4.0 \mathrm{M}$, $8.0 \mathrm{M}$ の条件で蒸解時間を 4 時間にした実験を行った。 その際，蒸解温度は $120^{\circ} \mathrm{C}$ 及び $170^{\circ} \mathrm{C}$ とた。

\section{5 中性亜硫酸ナトリウム蒸解}

濃度 $0.2 \mathrm{M}, 0.5 \mathrm{M}, 1.0 \mathrm{M}$ の曲硫酸ナトリウム溶 液で蒸解した。蒸解時間, 液比は水酸化ナトリウム一 段蒸解と同一であり, 蒸解温度は $120^{\circ} \mathrm{C}$ 及び $170^{\circ} \mathrm{C} の$ 2 系列で行った。

\section{6 亜塩素酸塩を用いた脱リグニン処理}

イネワラ葉鞘の粉末 $1 \mathrm{~g}$ を三角フラスコにとり, $100 \mathrm{ml}$ の $0.2 \mathrm{M}$ 酢酸塩緩衝液（pH 3.5）を加えた。 これに亜塩素酸ナトリウム $0.2 \mathrm{~g}$ を加えて温浴中で反 応を行った。反応温度は $75-80^{\circ} \mathrm{C}$, 反応時間は 1 時 
間とした。この処理を 1 回から 6 回まで行い， 6 種の 脱リグニン試料を調製した。

亜塩素酸塩によって 6 回処理した試料を，塩素処理 によってさらに脱リグニンした。塩素処理の条件は, 試料濃度 $3 \%$, 塩素比 0.07 及び 0.2 とし, 室温で 1 時間反応を行った。

塩素処理とは別に, 亜塩素酸塩処理を 6 回行った試 料についてアルカリ抽出を行った。反応温度は $20^{\circ} \mathrm{C}$, 反応時間を 35 分, 試料濃度を $4 \%$ とし, 水酸化ナ卜 リウム溶液の濃度を $5 \%, 10 \%, 17.5 \%$ に変えて行った。

\section{7 化学分析}

\section{7 .1 灰分及びシリカの定量}

予女科量した磁性るつぼに試料 0.5 $-1.0 \mathrm{~g}$ を入れ, 電気炉 $\left(700 \pm 10^{\circ} \mathrm{C}\right)$ で 3 時間強熱し, TAPPI 標準 試験法 ${ }^{14)}$ に準じて灰分量を測定した。

灰分を測定後, るつぼに $1.0 \mathrm{M}$ 塩酸を 10- $15 \mathrm{~m} l$ 加 えてガスバーナーで穏やかに 30 分加熱した。これを $1 \mathrm{G} 4$ ガラスフィルタで滤過し, $105^{\circ} \mathrm{C} て ゙$ 乾燥した後, TAPPI 標準試験法 ${ }^{15)}$ に準じてシリカ量を測定した。

\subsection{2 リグニンの定量及び中性糖分析}

イネワラのリグニンの定量には改良アセチルブロミ ド法を用いた ${ }^{16)}$ 。蒸解後, 試料中のリグニン量の定量

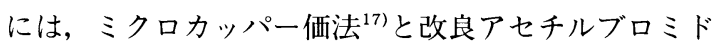
法桌を併用した。

中性糖の分析にはアルジトール・アセテート法を用 いた ${ }^{18)}$ 。

\section{3. 結果及び考察}

イネワラの蒸解過程において, パルプ中にシリカを できる限り保持すべきなのか，あるいは，除くべきな のかは，イネワラパルプから作られる紙の使用目的に よると考えられる。パルプに含まれる非繊維細胞のう ち, シリカに富む表皮細胞は紙の強度を低下させてい る1。一方，シリカを含むパルプから調製した紙は良 好な液体浸透性とインクジェット記録性を与えるとい う報告もある ${ }^{7), 8)}$ 。

いずれにせよ, 蒸解条件によって脱シリカ反応がど う影響されるのかをを詳細に検討することは重要な課 題であると考えられる。そこで本研究では, イネワラ を構成する組織のうち $40 \%$ から $45 \%$ を占め, シリカ 濃度が高い葉鞘を用いて, 種々の条件で蒸解を行い, シリカの脱離と他の細胞壁構成成分の溶出挙動一特に 脱リグニンーとの間にどのような相関があるかを詳細 に検討した。脱リグニンの指標としてはカッパー価を 用いた。本研究では, 蒸解液の液性が酸性からアルカ リ性までと幅広く, 脱リグニン反応も酸化反応とイオ
Table 1 Analytical results of rice straw sheath(\%)

\begin{tabular}{llr}
\hline Extractives & & 4.2 \\
Ash & Silica & 22.8 \\
& Others & 2.0 \\
Lignin(Acetyl bromide method) & 13.4 \\
Neutral Sugars & Rhamnose & 0.4 \\
& Arabinose & 3.5 \\
& Xylose & 19.8 \\
& Mannose & 0.2 \\
& Glucose & 32.3 \\
& Galactose & 0.9 \\
\hline
\end{tabular}

ン反応の両者を検討の対象としているので, 全ての蒸 解においてカッパー価とリグニン量の間に同一の関係 が成立しているという確証はないが, 実際上の観点か ら, カッパー価を単一の指標として各蒸解条件を比較 した。実験に利用したイネワラ葉鞘の構成成分は表 1 に示した。

\section{1 水酸化ナトリウムの濃度が脱シリカに及ぼす 影響}

図 1-A は, ソーダ蒸解と酸素・アルカリ蒸解にお ける脱シリカ度と, 得られたパルプのカッパー価の関 係をプロットしたものである。水酸化ナトリウム濃度 を $0.01 \mathrm{M}$ から $2.0 \mathrm{M}$ まで変化させた場合, 水酸化ナ トリウム濃度 $0.1 \mathrm{M}$ での蒸解によってカッパー価 17 まで脱リグニンが進行する一方で, 脱シリカは約 40\%に留まっている。これ以上の水酸化ナトリウム濃 度では, シリカの除去率が急激に高くなった。この急 激な脱シリカ度の上昇が, アルカリ性の強さによるも のか，あるいは，脱リグニンに必然的に伴うものかを 検討するために, $0.05 \mathrm{M}$ という比較的薄い水酸化十 トリウムによる 4 段までの多段蒸解を行ってみた。こ の結果図 1-A に示すように, 脱シリカと脱リグニン の関係は, 単段のソーダ蒸解とほとんど同様の挙動を 示した。すなわち, 蒸解過程での脱シリカ度の急激な 上昇は, 脱リグニンに伴うものであることが示唆され た。一方, $0.1 \mathrm{M}$ での単段蒸解と $0.05 \mathrm{M}$ での 2 段蒸 解を比較すると, 使用したアルカリ量としては同一で あるにもかかわらず, 脱シリカ度は大きく異なってい る。 2 段蒸解では 1 段蒸解と比べると, 反応時間, 液 量とも 2 倍になることを考虑すると, この結果は, 脱 シリカの進行が蒸解液に対するシリカの溶解度と溶解 速度によって影響されることを示唆している。

カッパー価が 10 以下になるまで蒸解すると単段で 


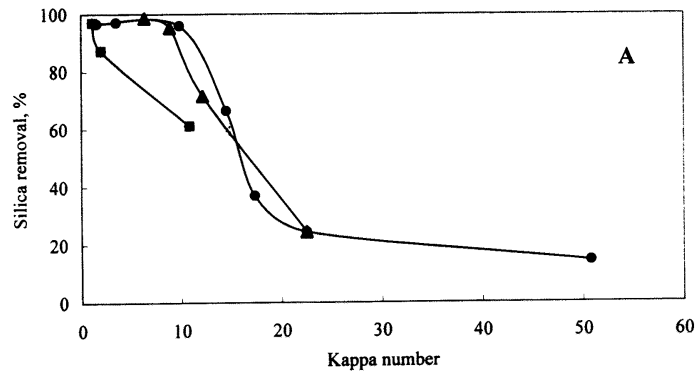

$0.01,0.05,0.1,0.2,0.5,1.0,2.0 \mathrm{M} \mathrm{NaOH}$, $120^{\circ} \mathrm{C}, 2 \mathrm{~h}$.

$\Delta ; 0.05 \mathrm{M} \mathrm{NaOH}, 120^{\circ} \mathrm{C}, 2 \mathrm{~h}$. (repeated runs : $1-4$ times) ; $\mathrm{O}_{2}: 0.3 \mathrm{MPa}, 120^{\circ} \mathrm{C}, 2 \mathrm{~h}, \mathrm{NaOH}: 10,20,40 \%$ on pulp.

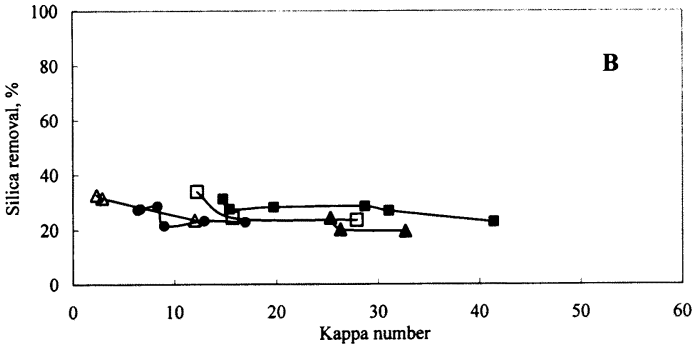

; $0.5,1.0,2.0,4.0,8.0,12.0 \mathrm{M} \mathrm{NH}_{3}, 120^{\circ} \mathrm{C}, 2 \mathrm{~h}$ $\square ; 2.0,4.0,8.0 \mathrm{M} \mathrm{NH}_{3}, 120^{\circ} \mathrm{C}, 4 \mathrm{~h}$

$\Delta ; 0.2,0.5,1.0 \mathrm{M} \mathrm{Na}_{2} \mathrm{SO}_{3}, 120^{\circ} \mathrm{C}, 2 \mathrm{~h}$

$\triangle ; 0.2,0.5,1.0 \mathrm{M} \mathrm{Na}_{2} \mathrm{SO}_{3}, 170^{\circ} \mathrm{C}, 2 \mathrm{~h}$

- $\mathrm{NaClO}_{2} 0.2 \mathrm{~g} / \mathrm{g}$ (on meal), each stage : $75^{\circ} \mathrm{C}, 1 \mathrm{~h}$, $0.2 \mathrm{M}$ acetate buffer $\mathrm{pH} 3.5$

$\mathrm{NaClO}_{2}$ treatment was repeated 6 times

Fig.1 Relationship between kappa number and silica removal under various cooking conditions

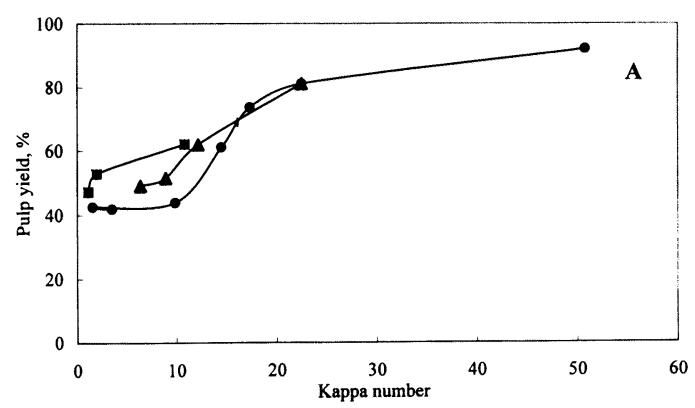

$0.01,0.05,0.1,0.2,0.5, \quad 1.0,2.0 \mathrm{M} \mathrm{NaOH}$, $120^{\circ} \mathrm{C}, 2 \mathrm{~h}$.

$\Delta ; 0.05 \mathrm{M} \mathrm{NaOH}, 120^{\circ} \mathrm{C}, 2 \mathrm{~h}$. (repeated runs : $1-4$ times)

口 $\mathrm{O}_{2}: 0.3 \mathrm{MPa}, 120^{\circ} \mathrm{C}, 2 \mathrm{~h}, \mathrm{NaOH}: 10,20,40 \%$ on pulp.

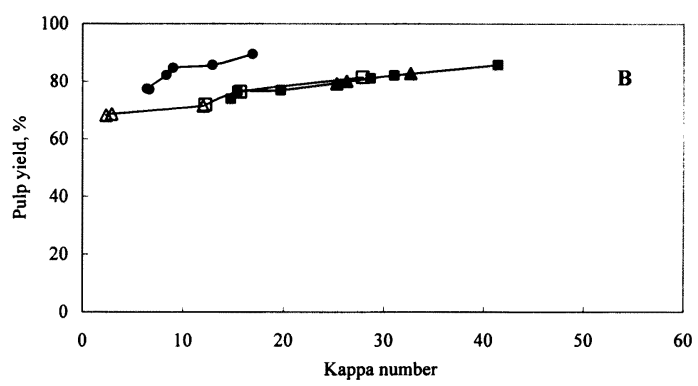

; $0.5,1.0,2.0,4.0,8.0,12.0 \mathrm{M} \mathrm{NH}_{3}, 120^{\circ} \mathrm{C}, 2 \mathrm{~h}$ $\square ; 2.0,4.0,8.0 \mathrm{M} \mathrm{NH}_{3}, 120^{\circ} \mathrm{C}, 4 \mathrm{~h}$

$\Delta ; 0.2,0.5,1.0 \mathrm{M} \mathrm{Na}_{2} \mathrm{SO}_{3}, 120^{\circ} \mathrm{C}, 2 \mathrm{~h}$

$\triangle ; 0.2,0.5,1.0 \mathrm{M} \mathrm{Na}_{2} \mathrm{SO}_{3}, 170^{\circ} \mathrm{C}, 2 \mathrm{~h}$

: $\mathrm{NaClO}_{2} 0.2 \mathrm{~g} / \mathrm{g}$ (on meal), each stage: $75^{\circ} \mathrm{C}, 1 \mathrm{~h}$, $0.2 \mathrm{M}$ acetate buffer $\mathrm{pH} 3.5$

$\mathrm{NaClO}_{2}$ treatment was repeated 6 times

Fig.2 Relationship between kappa number and pulp yield under various cooking conditions

も多段でも，脱シリカ度はほぼ $100 \%$ に達する。パル プ収率を見ると（図2-A），カッパー価が13より低 い領域において，多段蒸解の方がパルプ収率が高い。 この領域では，両蒸解法ともに脱シリカ度はほぼ 100\%に達しているので，パルプ収率の差は，炭水化 物収率の差である。すなわち，炭水化物の崩壊を抑え て脱リグニンを進める上で，希アルカリ繰り返し処理 による多段蒸解は有効であると考えられる。

\section{2 酸素・アルカリ蒸解が脱シリカに及ぼす影響} 中野らはイネワラの酸素・アルカリ蒸解でシリカが ほぼ完全に除去されることを報告したが4)，李らは酸 素・アルカリ蒸解ではシリカの保持率が高いと報告し ている ${ }^{7), 8)}$ 。本研究では, 3 レベルの水酸化ナトリウ
ム量で酸素・アルカリ蒸解して, 脱リグニンと脱シリ カの関係を調べた。図 1-A に示すように,ソーダ蒸 解と比較するとシリカの脱離は抑えられており，ソー 名蒸解では脱シリカ度がほぼ100\%に達するカッパー 価 11 において, 酸素・アルカリ蒸解での脱シリカ度 は $60 \%$ に過ぎない。しかし，リグニンがほほ完全に 脱離する条件では, 脱シリカ度はほぼ 100\%に達する。 シリカの脱離に関しては, 当然, 蒸解液の $\mathrm{pH}$ に強く 依存することが考えられる。後述 (3.6 節)するように, 蒸解後の蒸解液 $\mathrm{pH}$ と脱シリカの関係についてソーダ 蒸解と比較してみると（図 3)，興味深いことに，同 一 $\mathrm{pH}$ での比較ではソーダ蒸解よりも酸素・アルカリ 蒸解の方が脱シリカが進んでいることがわかった。こ 


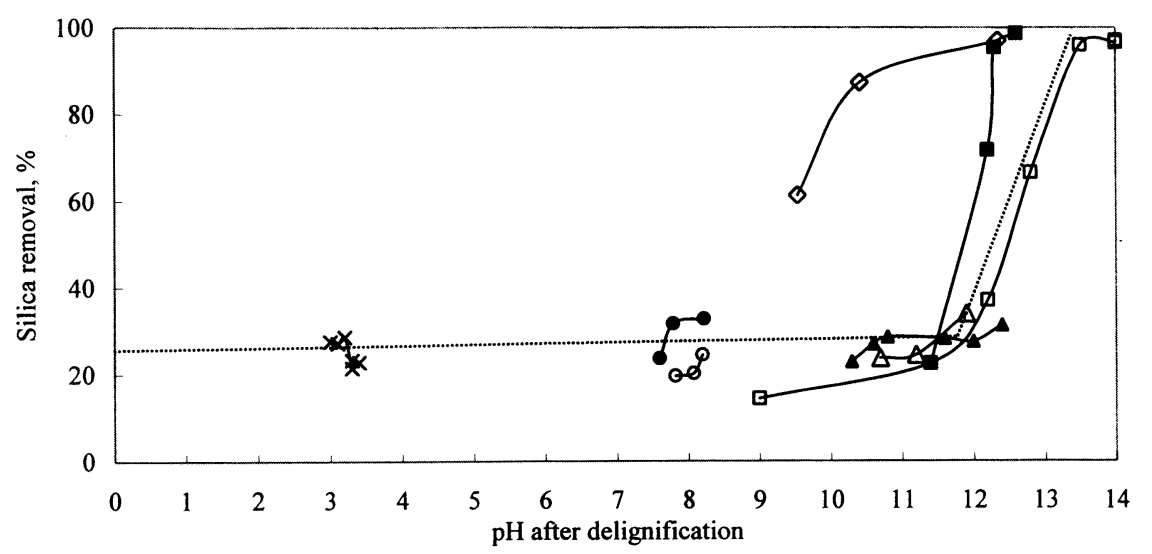

\begin{abstract}
$\square ; 0.01,0.05,0.1,0.2,0.5,1.0,2.0 \mathrm{M} \mathrm{NaOH}, 120^{\circ} \mathrm{C}, 2 \mathrm{~h}$
; $0.05 \mathrm{M} \mathrm{NaOH}, 120^{\circ} \mathrm{C}, 2 \mathrm{~h}$ (repeated runs: $1-4$ times)

$\Delta ; 0.5,1.0,2.0,4.0,8.0,12.0 \mathrm{M} \mathrm{NH}_{3}, 120^{\circ} \mathrm{C}, 2 \mathrm{~h}$

$\triangle ; 2.0,4.0,8.0 \mathrm{M} \mathrm{NH}_{3}, 120^{\circ} \mathrm{C}, 4 \mathrm{~h}$

$0 ; 0.2,0.5,1.0 \mathrm{M} \mathrm{Na}_{2} \mathrm{SO}_{3}, 120^{\circ} \mathrm{C}, 2 \mathrm{~h}$

; $0.2,0.5,1.0 \mathrm{M} \mathrm{Na}_{2} \mathrm{SO}_{3}, 170^{\circ} \mathrm{C}, 2 \mathrm{~h}$

$\diamond ; \mathrm{O}_{2}: 0.3 \mathrm{MPa}, 120^{\circ} \mathrm{C}, 2 \mathrm{~h}, \mathrm{NaOH}: 10,20,40$ on pulp

$\times ; \mathrm{NaClO}_{2} 0.2 \mathrm{~g} / \mathrm{g}$ (on meal), each stage : $75^{\circ} \mathrm{C}, 1 \mathrm{~h}, 0.2 \mathrm{M}$ acetate buffer $\mathrm{pH} 3.5$

$\mathrm{NaClO}_{2}$ treatment was repeated 6 times
\end{abstract}

Fig.3 Relationship between silica removal and $\mathrm{pH}$ after delignification

のことから, 酸素・アルカリ蒸解で脱シリカが抑えら れるのは，蒸解中に $\mathrm{pH}$ が低下し，相当に低い $\mathrm{pH}$ で 脱リグニンを進めたときに限られるのではないかと推 測される。

\section{3 アンモニア蒸解が脱シリカに及ぼす影響}

水酸化ナトリウムを用いた場合には，アルカリ濃度 をかなり低く保ってもシリカの脱離が進んでしまうこ とがわかったので, より弱いアルカリ条件で脱りグニ ンを行うために，アンモニアを用いて蒸解した。その 結果を図 1-B に示す。反応温度は $120^{\circ} \mathrm{C}$ とし，2 時間 の処理と 4 時間の処理の二通りを行った。試験した範 囲の条件では，カッパー価 12 までしか脱リグニンで きなかったが, ソーダ蒸解に比べると脱シリカ度が低 い。アンモニアでの脱リグニンをさらに進めた場合の

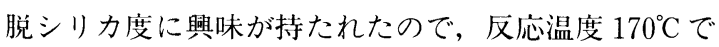
の蒸解も行ったが, それ以上の脱リグニンは達成され なかった。

反応時間が 2 時間のものよりも 4 時間のものの方が 脱シリカが抑えられているが，これは，4時間処理の 方が反応後の蒸解液 $\mathrm{pH}$ が低くなっていることによる と考えられる。李らは酸素一アルカリ蒸解中における シリカの溶出及び再沈積の挙動について検討を行った 結果から, 蒸解液に溶解したシリカが蒸解液の $\mathrm{pH} の$ 低下とともに再沈積することを推測している ${ }^{199}$ 。これ
と同様に, アンモニア蒸解でも長時間の蒸解によって ある程度脱りグニンが促進され，それによって $\mathrm{pH} の$ 低下が起こりシリカの再沈積が起こったと考えること ができよう。

アンモニア蒸解では, カッパー価が 15 となったア ンモニア濃度 $12.0 \mathrm{M}, 120^{\circ} \mathrm{C}, 2$ 時間の蒸解でも, パ ルプ収率は $72 \%$ と非常に高い。これは, パルプのシ リカ含量が高い $(21 \%$, 対パルプ) ことにもよるが, 炭水化物収率を見てもかなり高いことがわかる(表 2)。

\section{4 中性亜硫酸塩蒸解が脱シリカに及ぼす影響}

弱いアルカリ条件でアンモニア蒸解の場合以上に脱 リグニンを進めるために, 中性亜硫酸塩蒸解を試みた。 図 1-Bには, 反応温度として $120^{\circ} \mathrm{C}$ ののと, 中野ら と同じ $170^{\circ} \mathrm{C} の も の の ， 2$ 系列の実験結果を示した。 $120^{\circ} \mathrm{C}$ での蒸解では, カッパー価 25 以下にまで脱リグ

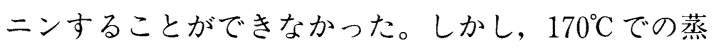
解では, 中野らが報告しているのと同様に年, 非常に 高い脱リグニンが達成されるとともに脱シリカ度も 35\%のレベルに留まっている。

パルプ収率についても, 図 2 の A と B とにそれぞ れ示すように, 中性亜硫酸塩蒸解の方がソー夕゙蒸解よ りもかなり高い結果が得られた。すなわち, ほぼ完全 に脱リグニンされた時, ソーダ蒸解のパルプ収率は 41-44\%だったが，亜硫酸ナトリウム蒸解では約 $68 \%$ 
Table 2 Results of various cooking of rice straw.

\begin{tabular}{|c|c|c|c|c|c|c|c|c|}
\hline & Conc. & Temp. & Time & $\begin{array}{c}\text { Pulp } \\
\text { yield, \% }\end{array}$ & $\begin{array}{c}\text { Kappa } \\
\text { No }\end{array}$ & $\begin{array}{c}\text { Delignification* } \\
\%\end{array}$ & $\begin{array}{c}\text { Carbohydrate } \\
\text { yield* } \%\end{array}$ & $\begin{array}{c}\text { Silica } \\
\% \text { on pulp }\end{array}$ \\
\hline \multirow[t]{7}{*}{$\mathrm{NaOH}$} & $0.01 \mathrm{M}$ & $120^{\circ} \mathrm{C}$ & $2 \mathrm{~h}$ & 92.1 & 50.8 & 47.8 & 98.8 & 21.2 \\
\hline & $0.05 \mathrm{M}$ & $120^{\circ} \mathrm{C}$ & $2 \mathrm{~h}$ & 81.2 & 22.5 & 79.4 & 96.7 & 21.2 \\
\hline & $0.1 \mathrm{M}$ & $120^{\circ} \mathrm{C}$ & $2 \mathrm{~h}$ & 73.7 & 17.4 & 85.7 & 92.1 & 19.5 \\
\hline & $0.2 \mathrm{M}$ & $120^{\circ} \mathrm{C}$ & $2 \mathrm{~h}$ & 61.1 & 14.5 & 90.0 & 83.6 & 12.5 \\
\hline & $0.5 \mathrm{M}$ & $120^{\circ} \mathrm{C}$ & $2 \mathrm{~h}$ & 43.8 & 9.9 & 95.1 & 67.5 & 2.1 \\
\hline & $1.0 \mathrm{M}$ & $120^{\circ} \mathrm{C}$ & $2 \mathrm{~h}$ & 42.5 & 1.6 & 99.4 & 66.5 & 1.8 \\
\hline & $2.0 \mathrm{M}$ & $120^{\circ} \mathrm{C}$ & $2 \mathrm{~h}$ & 41.9 & 3.5 & 98.4 & 65.5 & 1.6 \\
\hline \multicolumn{9}{|l|}{$\mathrm{NaOH}$} \\
\hline 1 st treat & $0.05 \mathrm{M}$ & $120^{\circ} \mathrm{C}$ & $2 \mathrm{~h}$ & 81.2 & 22.5 & 79.4 & 96.7 & 21.7 \\
\hline 2 times repeat & $0.05 \mathrm{M}$ & $120^{\circ} \mathrm{C}$ & $2 \mathrm{~h}$ & 62.0 & 12.2 & 91.7 & 86.8 & 10.4 \\
\hline 3 times repeat & $0.05 \mathrm{M}$ & $120^{\circ} \mathrm{C}$ & $2 \mathrm{~h}$ & 51.5 & 8.9 & 95.0 & 80.3 & 2.0 \\
\hline 4 times repeat & $0.05 \mathrm{M}$ & $120^{\circ} \mathrm{C}$ & $2 \mathrm{~h}$ & 49.1 & 6.4 & 96.3 & 77.8 & 0.6 \\
\hline \multirow[t]{3}{*}{$\mathrm{O}_{2}$-alkali } & $10 \%$ & $120^{\circ} \mathrm{C}$ & $2 \mathrm{~h}$ & 62.1 & 10.8 & 92.6 & 82.3 & 13.9 \\
\hline & $20 \%$ & $120^{\circ} \mathrm{C}$ & $2 \mathrm{~h}$ & 52.8 & 2.0 & 98.8 & 78.3 & 5.4 \\
\hline & $40 \%$ & $120^{\circ} \mathrm{C}$ & $2 \mathrm{~h}$ & 47.3 & 1.1 & 99.3 & 73.3 & 1.4 \\
\hline \multirow[t]{6}{*}{$\mathrm{NH}_{3}$} & $0.5 \mathrm{M}$ & $120^{\circ} \mathrm{C}$ & $2 \mathrm{~h}$ & 85.8 & 41.4 & 60.3 & 98.0 & 20.5 \\
\hline & $1.0 \mathrm{M}$ & $120^{\circ} \mathrm{C}$ & $2 \mathrm{~h}$ & 82.1 & 31.1 & 71.2 & 96.2 & 20.3 \\
\hline & $2.0 \mathrm{M}$ & $120^{\circ} \mathrm{C}$ & $2 \mathrm{~h}$ & 81.1 & 28.7 & 74.0 & 95.7 & 20.1 \\
\hline & $4.0 \mathrm{M}$ & $120^{\circ} \mathrm{C}$ & $2 \mathrm{~h}$ & 76.9 & 19.7 & 82.8 & 91.5 & 21.3 \\
\hline & $8.0 \mathrm{M}$ & $120^{\circ} \mathrm{C}$ & $2 \mathrm{~h}$ & 76.5 & 15.4 & 88.0 & 91.7 & 21.6 \\
\hline & $12.0 \mathrm{M}$ & $120^{\circ} \mathrm{C}$ & $2 \mathrm{~h}$ & 73.9 & 14.7 & 88.0 & 89.2 & 21.2 \\
\hline \multirow[t]{3}{*}{$\mathrm{NH}_{3}$} & $2.0 \mathrm{M}$ & $120^{\circ} \mathrm{C}$ & $4 \mathrm{~h}$ & 81.4 & 27.9 & 74.5 & 95.9 & 21.4 \\
\hline & $4.0 \mathrm{M}$ & $120^{\circ} \mathrm{C}$ & $4 \mathrm{~h}$ & 76.3 & 15.7 & 86.9 & 91.7 & 22.6 \\
\hline & $8.0 \mathrm{M}$ & $120^{\circ} \mathrm{C}$ & $4 \mathrm{~h}$ & 71.8 & 12.2 & 90.4 & 87.7 & 21.0 \\
\hline \multirow[t]{3}{*}{$\mathrm{Na}_{2} \mathrm{SO}_{3}$} & $0.2 \mathrm{M}$ & $120^{\circ} \mathrm{C}$ & $2 \mathrm{~h}$ & 82.8 & 32.7 & 69.7 & 95.5 & 22.2 \\
\hline & $0.5 \mathrm{M}$ & $120^{\circ} \mathrm{C}$ & $2 \mathrm{~h}$ & 80.1 & 26.3 & 76.7 & 93.9 & 22.7 \\
\hline & $1.0 \mathrm{M}$ & $120^{\circ} \mathrm{C}$ & $2 \mathrm{~h}$ & 79.2 & 25.3 & 77.5 & 93.2 & 21.8 \\
\hline \multirow[t]{3}{*}{$\mathrm{Na}_{2} \mathrm{SO}_{3}$} & $0.2 \mathrm{M}$ & $170^{\circ} \mathrm{C}$ & $2 \mathrm{~h}$ & 71.4 & 12.0 & 90.4 & 79.5 & 22.9 \\
\hline & $0.5 \mathrm{M}$ & $170^{\circ} \mathrm{C}$ & $2 \mathrm{~h}$ & 68.7 & 2.9 & 98.5 & 80.3 & 22.3 \\
\hline & $1.0 \mathrm{M}$ & $170^{\circ} \mathrm{C}$ & $2 \mathrm{~h}$ & 68.2 & 2.3 & 99.0 & 80.4 & 22.1 \\
\hline
\end{tabular}

${ }^{*}$ Delignification and carbohydrate yields were obtained based on the assumption, kappa number $\times 0.15=$ lignin $(\%$ on pulp $)$

であった。表 2 の炭水化物収率で評価しても, 中性亜 硫酸塩蒸解はソーダ蒸解よりもかなり高い。したがっ て，シリカをパルプ中に保持する蒸解法としては，中 性亜硫酸塩蒸解法は極めて有望であると言えよう。

3.5 酸性での脱リグニン処理が脱シリカに及ぼす 影響

アルカリ系での実験結果から, 反応系の $\mathrm{pH}$ がシリ カの脱離に大きく影響しているということが確認され
たので, 続いて, 酸性下での脱リグニン処理が脱シリ カに及ぼす影響ついて検討した。酢酸酸性下での反応 である亜塩素酸塩による脱リグニンを行い，脱リグニ ンと脱シリカとの関係を調べた (図1-B)。亜塩素酸 塩処理を 6 回まで行った各試料のカッパー洒はそれぞ れ 16.9，12.9，9.0，8.4，6.4，6.7であったが脱シ リカ度は22.8-27.8\%と極めて低く抑えられているこ とが分かった。 
ここで得られた高度にシリカを保持している試料を モデルとして用い, 漂白反応が脱シリカに及ぼす影響 を検討した。すなわち，ここで得られた試料について， 室温での塩素による脱リグニン処理及び室温でのアル カリによる抽出を試みた。表 3 に示されるように, 酸 性下での反応である塩素処理を行った場合, シリカの 脱離はほとんど進行しないことがわかった。すなわち， イネワラの塩素処理は脱シリカを抑えたままで, 効果 的に脱りグニンを進めると考えられる。一方, 室温で のアルカリ抽出では脱シリカは進行したが, 高温での アルカリ蒸解よりも脱シリカが抑えられることが分か つた。ここで用いたアルカリ抽出条件は，5\%，10\%， $17.5 \%$ というかなり高濃度なもの（ $\alpha$-セルロース調 製条件に近い）であり， $\mathrm{pH}$ も反応前後ともに14を 示すような強いアルカリ条件であるが, 室温での処理 であるため, 蒸解の場合のようには脱シリカが進行し なかったものと考えられる。シリカの溶出には, アル カリ濃度とともに温度が重要なファクターであること が明らかになった。

\section{6 蒸解液 $\mathbf{p H}$ と脱シリカの関係}

蒸解後の各蒸解液の $\mathrm{pH}$ と脱シリカおよび脱リグニ ンとの関係を，それぞれ罒 3 および図 4 にまとめた。 図 3 から, 脱シリカが蒸解液の $\mathrm{pH}$ に依存しているこ とは明らかである。アンモニアあるいは中性亜硫酸塩 蒸解では, $\mathrm{pH}$ が低いことがシリカの脱離を抑えてい ると考えられる。この図から，脱シリカを進めるには， 蒸解後 $\mathrm{pH} 11.5$ 以上での蒸解を行い, 脱シリカを抑 えるにはそれ以下の $\mathrm{pH}$ での蒸解を行えばよいことが 示唆される。

この中で特異的なのは，すでに 3.2 節で述べたよう に酸素・アルカリ蒸解である。図 4 に示したように, 水酸化ナトリウム単独での蒸解に比べて, 同程度のア ルカリ履歴を経ていると考えられる酸素・アルカリ蒸
解の方が, 脱リグニンが進行しているのは当然である が, シリカの脱離も進行していた。つまり, 酸素・ア ルカリ蒸解では, $\mathrm{pH}$ が比較的低くても高度の脱リグ ニンが達成できるため, 同程度の脱りグニンを与える アルカリ単独での蒸解よりも, シリカの保持率が高く なる。しかし, 同程度の $\mathrm{pH}$ の履歴で比較すると, 酸 素・アルカリ蒸解の方がシリカの脱離が大きくなった。 これは, 脱シリカ反応が単に蒸解液の $\mathrm{pH}$ に依存する だけでなく，リグニンあるいは炭水化物の脱離にも依 存していることを示唆しているとも考えられる。酸素 の存在がシリカの溶解を促進しているとも考えられよ う。詳しい理由は今後の検討課題であるが, 酸素・ア ルカリ蒸解ではシリカの脱離が抑えられると言う李等 の主張(27),8)，必ずしも妥当ではないと言えよう。

\section{4. 結 論}

酸性からアルカリ性にいたる幅広い液性の種々の蒸 解液を用いて, イネワラの脱リグニン反応を行い, 脱 リグニンと脱シリカとの関係を検討した。シリカをな るべく保持する蒸解法としては, 覀硫酸塩蒸解とアン モニア蒸解, あるいは, 酸性下での蒸解を挙げること ができ, シリカを除去する蒸解法としては, ソーダ蒸 解と酸素・アルカリ蒸解などを挙げることができる。 ここで注目したいのは, 約 $30 \%$ までの脱シリカは, アルカリ性下でも, 中性下でも, 酸性下でも, 脱リグ ニンに伴って進行するが, それ以上の脱シリカは反応 系のアルカリの強さと温度に強く依存しているように 思えるという点である。すなわち, 脱りグニンの進行 と強い相関を持って脱離するシリカと, 脱リグニンと は無関係にアルカリの強さに依存して脱離するシリカ が存在する。この区分けが, 単なる見かけ上のことな のか, あるいは, シリカの存在形態に関わる本質的な 区分けなのかは，今後の検討課題である。

Table 3 Treatment of holocellulose by sodium hydroxide and chlorine

\begin{tabular}{|c|c|c|c|c|c|c|}
\hline & \multirow{3}{*}{$\begin{array}{c}\text { Before } \\
\text { treatment* }\end{array}$} & \multicolumn{5}{|c|}{ After treatment } \\
\hline & & \multicolumn{3}{|c|}{$\mathrm{NaOH}$ extractions } & \multicolumn{2}{|c|}{$\begin{array}{c}\mathrm{Cl}_{2} \text { treatment } \\
\text { (Chlorine multiple) }\end{array}$} \\
\hline & & $5 \%$ & $10 \%$ & $17.5 \%$ & 0.07 & 0.2 \\
\hline $\begin{array}{c}\text { Yield } \\
(\% \text { on rice straw meal })\end{array}$ & 77.1 & 58.7 & 52.3 & 48.8 & 74.8 & 74.1 \\
\hline $\begin{array}{c}\text { Silica content } \\
(\%)\end{array}$ & 21.1 & 21.9 & 21.6 & 16.2 & 21.5 & 21.6 \\
\hline
\end{tabular}

${ }^{*}$ Holocellulose was obtained by repeated treatment ( 6 times) with sodium chlorite 


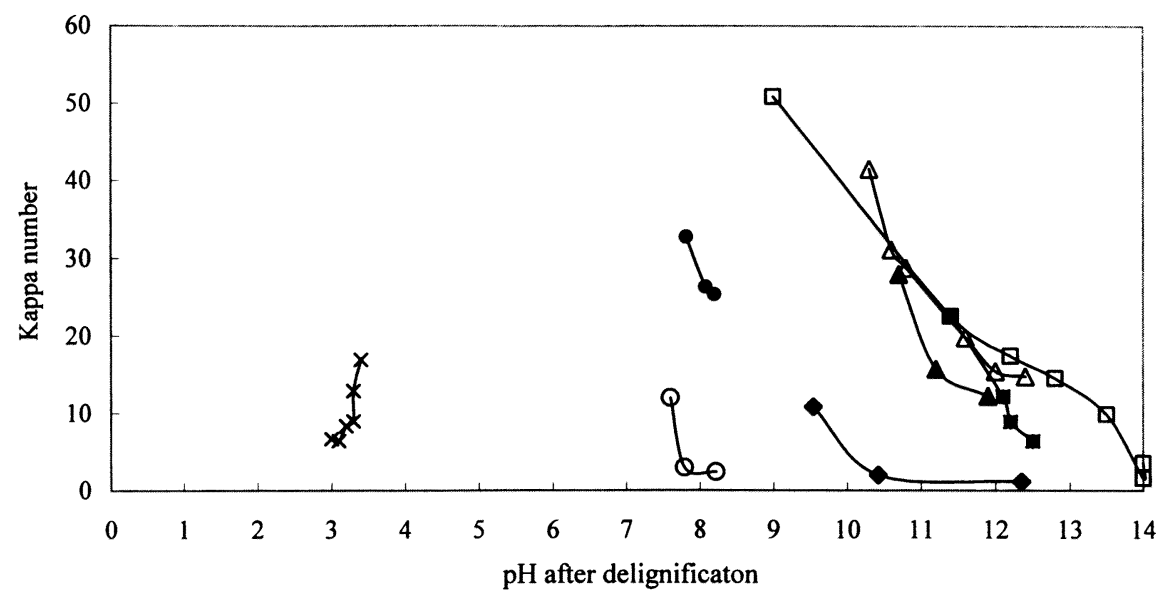

$\square ; 0.01,0.05,0.1,0.2,0.5,1.0,2.0 \mathrm{M} \mathrm{NaOH}, 120^{\circ} \mathrm{C}, 2 \mathrm{~h}$

$; 0.05 \mathrm{M} \mathrm{NaOH}, 120^{\circ} \mathrm{C}, 2 \mathrm{~h}$ (repeated runs : $1-4$ times)

$\triangle ; 0.5,1.0,2.0,4.0,8.0,12.0 \mathrm{M} \mathrm{NH}_{3}, 120^{\circ} \mathrm{C}, 2 \mathrm{~h}$

$\Delta ; 2.0,4.0,8.0 \mathrm{M} \mathrm{NH}_{3}, 120^{\circ} \mathrm{C}, 4 \mathrm{~h}$

; $0.2,0.5,1.0 \mathrm{M} \mathrm{Na}_{2} \mathrm{SO}_{3}, 120^{\circ} \mathrm{C}, 2 \mathrm{~h}$

; $0.2,0.5,1.0 \mathrm{M} \mathrm{Na}_{2} \mathrm{SO}_{3}, 170^{\circ} \mathrm{C}, 2 \mathrm{~h}$

$\checkmark ; \mathrm{O}_{2}: 0.3 \mathrm{MPa}, 120^{\circ} \mathrm{C}, 2 \mathrm{~h}, \mathrm{NaOH}: 10,20,40$ on pulp

$\times ; \mathrm{NaClO}_{2} 0.2 \mathrm{~g} / \mathrm{g}$ (on meal), each stage : $75^{\circ} \mathrm{C}, 1 \mathrm{~h}, 0.2 \mathrm{M}$ acetate buffer $\mathrm{pH} 3.5$

$\mathrm{NaClO}_{2}$ treatment was repeated 6 times

Fig.4 Relationship between kappa number and $\mathrm{pH}$ after delignification

\section{引用文献}

1）森本正和：紙パ技協誌，51（6），65-84（1997）。

2）泥谷直大：紙パルプ技術夕イムズ，33（11），53$56(1990)$.

3）小林良生：紙八技協紙，43（6)，535-557（1998）。

4）中野準三，北仲由美子，嘉代拓末，江前敏晴，李 忠正：紙八技協紙， 48 (8)，1078-1083（1994）。

5) M. L. Miller : Tappi 1982 Pulping Conference Proceedings, TAPPI PRESS, 313-317 (1982)

6）中野準三, 津田祐子, 伊藤秀司：第 64 回紙パル プ研究会要旨集, 16-19（1997）.

7）李 兵, 岡山隆之, 大江礼三郎：木材学会誌，41 (2), 170-178 (1995) .

8）李 兵, 岡山隆之, 佐渡 篤：木材学会誌， 42 (3), 272-278 (1996) .

9）戸坂固夫，林治助：紙八゚技協紙，38（2），215$223(1984)$.

10）戸坂图夫，林治助：紙パ技協紙，38（6），669674 (1984).

11) Ke-Li Chen, K. Tosaka and J. Hayasi :
Tappi J, 77 (7), 109-113 (1994).

12) C. H. Kang, S. C. Park, S. J. Park : IUMRS-ICA, 4 th, 1 (1997).

13) J. T. Jeyasingam, TAPPI Nonwood Plant Fiber Pulping, Progress Report No.16, 9 (1986)

14) TAPPI Standard Method, T 211 om-85, Tappi (1986).

15) TAPPI Standard Method, T 244 om-83, Tappi (1986).

16) K. Iiyama and A. F. A. Wallis : Wood Sci. Technol. 22, 271-280 (1988).

17) TAPPI Standard Method, UM 246, Tappi (1985).

18) A. B. Blakeney, P. J. Harris, R. T. Henry and B. A. Stone : Carbohydrate Research, 113, 291-299 (1983).

19）李 兵, 岡山隆之, 佐渡 篤, 島田勝広, 水元 和成：第 45 回日本木材学会要旨集, 315 (1995).

(受理 : '98.8.3) 